\title{
RESENHA|REVIEWS
}

MARX, Karl; BENSAID, Daniel. Os despossuídos: debates sobre a lei referente ao furto de madeira. Trad. Nélio Schneider e Mariana Echalar. São Paulo: Boitempo, 2017.

\section{OS DESPOSSUÍDOS: DEBATES SOBRE A LEI REFERENTE AO FURTO DE MADEIRA}

\author{
THE DISPOSSESSED: LAW DEBATES REGARDING THE THEFT OF WOOD
}

\section{Vitor Gabriel Garnica ${ }^{1}$}

Como Citar: GARNICA, Vitor Gabriel. Os despossuídos: debates sobre a lei referente ao furto de madeira. Trad. Nélio Schneider e Mariana Echalar. São Paulo: Boitempo, 2017. Scientia Iuris, Londrina, v. 25, n. 1, p. 203-205, mar. 2021. DOI: 10.5433/2178-8189.2018v22n2p203. ISSN: 2178-8189.

Resumo: A resenha do livro Os despossuídos, da editora Boitempo, traz à baila discussão sobre o Direito, o Estado e a propriedade privada. O livro é dividido em dois artigos. O primeiro é do autor Daniel Bensaid (2007), o qual trata sobre reflexões do texto original de Karl Marx e contém observações e reflexões importantes preparatórias para o segundo artigo contido no livro, da autoria de Marx. Busca-se, portanto, estabelecer a conexão entre ambos os textos e a importância que representam para o ramo jurídico no qual é proposto. Em suma, o livro traz aspectos e comentários sobre a Lei de Furto de Madeira na Alemanha e sobre os debates ocorridos durante sua tramitação na Dieta Renana em 1842, bem como aspectos sobre propriedade privada, Direito e Estado que perpassam a crítica contida nos autores.

Palavras-Chave: Crítica ao Direito; Lei do Furto de Madeira; Despossuídos.

Abstract: The review of the book The Dispossessed by Boitempo publishes a discussion on Law, State and Private Property. The book is divided into two articles. The first is by the author Daniel Bensaid (2007), in which he deals with reflections from Karl Marx's original text, containing important preparatory observations and reflections for the second article contained in the book. Therefore, it seeks to establish the connection between both texts and their importance for the legal branch of which it is proposed. Summary, the book brings aspects and comments about the Wood Theft Law in Germany and its debates during its processing in the Diet Renana in 1842, aspects about private property, law and the State permeate the criticism contained in the authors.

Keywords: Criticism of Law; Wood Theft Law; The dispossessed.

Os despossuídos, da Editora Boitempo, publicado em 2017, trouxe dois artigos a respeito da reflexão entre propriedade privada, Estado e direito. O primeiro é do filósofo francês Daniel Bensaid (2007), que faz considerações e reflexões preparatórias para o segundo artigo do texto

1 Mestrando do Programa de Direito Negocial da Universidade Estadual de Londrina. Bolsista pela CAPES. Endereço eletrônico: vitorgarnica@hotmail.com. Currículo Lattes: http://lattes.cnpq.br/5990451598884333. 
original de Karl Marx. Toma-se, enquanto ponto de partida, o debate da Lei referente ao Furto de Madeira na Alemanha em 1842 e também-as críticas que os autores levantam sobre o uso do Direito e do Estado na proteção da propriedade privada. Assim, revela-se a instrumentalização jurídica em prol de interesses privados; no caso em tela, dos proprietários florestais em detrimento dos pobres, em condição de miséria, coletores de madeira.

A razão desta resenha ser de grande valor à esta revista jurídica, é tratar sobre o direito enquanto instrumento para operacionalizar os interesses de uma classe sobre a outra (proprietários $\mathrm{x}$ coletores). Evidencia-se uma discussão rica ao ramo jurídico ao compreender a política estatal enquanto garantidora do interesse particular sobre o interesse público. Ora, discussão essa, que se evidencia nos dias de hoje. Constata-se na análise feita por Bensaid que as estruturas jurídicas do século XIX se perpetuam até os dias de hoje, sendo uma obra importante para compreender a Teoria Geral do Direito e do Estado.

O artigo, "Os despossuídos: Karl Marx, os ladrões de madeira e o Direito dos Pobres", de Daniel Bensaid, é divido em três partes e busca, sobretudo, contextualizar o momento histórico dos escritos da Gazeta Renana de 1842 (primeira parte), além da crítica ao direito (segunda parte). Outro ponto que vale destacar é sobre a contemporaneidade que o autor traz da discussão do século XIX para os dias de hoje (terceira parte).

$\mathrm{Na}$ primeira parte, o autor destaca a formação de uma nova forma de sociabilidade derivada das revoluções liberais baseada no idealismo hegeliano. A passagem do antigo regime para o capitalismo comercial necessitava de novas formas e instrumentos para efetivar a troca de mercadorias; nesse contexto, a formação dos Estados e o direito se conformam de forma a consolidar esse novo regime de acumulação e mercantilização. Diante dessa nova conjuntura, a definição de propriedade privada toma proporções para além do Direito Natural, pois a própria natureza está contida na propriedade privada. Outro efeito seria a quantificação do delito em pena, essa passagem se refere a como que o Direito Consuetudinário do pobre ao colher madeiras para a sua sobrevivência torna-se um crime segundo a Dieta Renana. Nesse ponto, o autor tece críticas ao Direito Consuetudinário ao servir os interesses dos proprietários florestais: se o costume não os beneficia, alega-se o Direito Formal do furto ao invés da coleta. Por fim, o autor destaca o papel do Estado, ao disponibilizar o monopólio da violência para a garantia dos direitos privados, uma vez que os efetiva utilizando os recursos públicos, tais como o sistema de fiscalização (agente público) e o próprio judiciário a fim de assegurar a relação contratual e a subjetividade jurídica da igualdade.

Já a segunda parte retoma a discussão da revolução inglesa enquanto potencializadora do fenômeno da propriedade privada por meio da ficção jurídica. Destaca-se a diferença entre posse e propriedade: enquanto a primeira é um fato, a segunda é construída por meio normativo. Relação essa perpassada para a apropriação do trabalho humano e o regime da acumulação.

Por fim, a terceira parte traz reflexões sobre o processo de acumulação capitalista nos dias de hoje, via mercado financeiro, e as noções de propriedade (intelectual e material). Assim, a mesma lógica é perpassada por outras condicionantes. O Estado continua a fomentar e a proteger o conhecimento em níveis privados (patentes), assim como a apropriação do meio ecológico. Conclui o autor, então, sobre a diferença entre a propriedade individual e a privada, que reside na apropriação dos bens para fins egoísticos (privada), enquanto a individual sugere a distribuição da produção e do saber sem aferir na individualidade dos sujeitos.

Parte-se para a análise do artigo de Karl Marx, "Debates sobre a Lei Referente ao Furto de Madeira", publicado pela Gazeta Renana no ano de 1942. Destaca-se que Marx era recém-formado em Direito, escreve primeiramente sobre a Liberdade da Imprensa, sendo esse artigo a segunda publicação do autor. Frisa-se que o texto é dividido em cinco suplementos que visam elucidar o uso de bens coletivos (madeira) em crime, a discussão se passa durante o trâmite da Lei na Dieta Renana (uma espécie de assembleia da Renânia - cidade natal de Marx). 
Nos cinco suplementos escritos sobre a discussão da Lei do Furto de Madeira, o autor primeiramente busca trazer a tipificação do delito e da pena. Em suma, a lei apresentava uma pena para os coletores de madeira (inclusive de natureza morta, aqueles ramos que não estavam mais presos às árvores) em propriedades florestais que antes eram garantidas pelo costume do Direito Consuetudinário, mas passa-se a configurar um tipo penal. Marx é incisivo em suas críticas pela troca da polarização dos verdadeiros criminosos, uma vez que o direito em sua ficção altera esses polos, pois "a população vê a pena, mas não vê o crime, e justamente por ver a pena onde não há crime não verá crime onde houver a pena" (MARX, 2017, p. 82).

Outro ponto de grande destaque é a utilização jurídica dos direitos, uma vez que "se esses direitos consuetudinários da nobreza são costumes contrários ao conceito de direito razoável, os direitos consuetudinários da pobreza são direitos contrários ao costume do direito positivo" (ibidem, p. 87). Em suma, o direito a ser positivado seria contra a condição vital de um grupo de pessoas que viviam da coleta, o que Marx constata que seria uma afronta aos próprios princípios do Direito. Por fim, a denúncia é latente ao incorporar o Estado aos interesses privativos. Denunciase que "a imparcialidade é a forma, não o conteúdo da sentença" (ibidem, p. 124). Portanto, o direito é uma defesa dos interesses de uma minoria já privilegiada, condena os que não tem acesso. Torna-se instrumento de legitimação da própria condição de exploração de uns sobre os outros, do privado sobre o coletivo.

Como Citar: GARNICA, Vitor Gabriel. Os despossuídos: debates sobre a lei referente ao furto de madeira. Trad. Nélio Schneider e Mariana Echalar. São Paulo: Boitempo, 2017. Scientia Iuris, Londrina, v. 25, n. 1, p. 203-205, mar. 2021. DOI: $10.5433 / 2178-8189.2018 v 22 n 2 p 203$. ISSN: 2178-8189. 